\title{
Intraoperative values of S-100 protein, myelin basic protein, lactate, and albumin in the CSF and serum of neurosurgical patients
}

\author{
J de Vries, W A M H Thijssen, S E A Snels, T Menovsky, N G M Peer, K J B Lamers
}

\begin{abstract}
Objectives-To assess the concentrations of $\mathrm{S}-100$ protein, myelin basic protein (MBP), and lactate, and the (CSF)/serum albumin ratio (Qalb) during intracranial neurosurgical procedures.

Methods-Samples of CSF from 91 patients with various CNS diseases were obtained by aspiration of cisternal CSF at the beginning of surgery (before starting surgical manipulation of the brain) and concentrations of S-100 protein, MBP, and lactate, and Qalb were determined. At the same time blood was sampled for determination of serum S-100 protein concentration. Patients were divided into three groups according to the aetiology of their CNS disease (intracranial haemorrhage, $\mathrm{n}=11$; benign intracranial mass lesion, $\mathrm{n}=52$; malignant neoplastic disease, $\mathrm{n}=28$ ). Radiological and intraoperative characteristics were documented.
\end{abstract}

Results-In each of these three groups median values of all four CSF variables measured were raised. The occurrence of brain oedema and a midline shift correlated significantly with raised concentrations of MBP and Qalb. Breaching of the arachnoid layer, documented at surgery for benign lesions, correlated with higher concentrations of MBP, lactate, CSF S-100 protein, and Qalb.

Conclusions-Intraoperative values of S-100 protein, MBP, lactate, and Qalb are increased in patients with intracranial haemorrhage, benign intracranial mass lesion, and malignant neoplastic disease. Breaching of the arachnoid layer and oedema is associated with higher concentrations of some of the aforementioned proteins. These biochemical data can serve as a basis for further research into CSF specific proteins.

(F Neurol Neurosurg Psychiatry 2001;71:671-674)

Keywords: S-100; myelin basic protein; neurosurgery; cerebrospinal fluid

S-100 protein (S-100) and myelin basic protein (MBP) are regarded as CNS specific proteins. S-100 protein constitutes a major component of the cytosol, predominantly in the glial cells. ${ }^{12}$ Myelin basic protein is detectable in developing oligodendroglia and is bound to the extracellular membranes of central and, to a lesser extent, peripheral myelin. ${ }^{34}$

These proteins will leak into the extracellular space after cell damage. Because the CSF is in close contact with the extracellular space, increased concentrations of S-100 and MBP in CSF may indicate CNS damage and may help to identify the cell type or part (glia or myelin) affected by the pathological process. Raised S-100 values can also be found in peripheral blood. It is not clear which route is followed by S-100 to appear in the peripheral blood.

Lactate can be used as an indicator for the extent of cerebral hypoxia. The CSF/serum albumin ratio (Qalb) is a measure for the extent of disruption of the blood-CSF barrier, although it is also supposed to be influenced to a lesser extent by disturbance of the blood-brain barrier.

Proteins specific to the CNS have been examined in several neurological disorders. ${ }^{15-11}$ However, in patients with brain tumours, S-100 concentrations have not yet been studied; MBP concentrations were evaluated in a recent study. ${ }^{12}$

In the present study, the values of S-100, MBP, lactate, and Qalb in CSF and the values of S-100 in serum of 91 neurosurgical patients with various intracranial CNS disorders were investigated intraoperatively but before any surgical manipulation of the brain. The aim was to document possible cell damage caused by the specific pathological process and thus already present before surgery. We did not take consecutive samples postoperatively because of the difficulty in obtaining cisternal CFS samples in follow up.

\section{Patients and methods}

PATIENTS

Ninety one patients ( 48 women and 43 men) operated on for various CNS diseases were studied. The median age was 48 years (range 1-79 years). Patients were divided into three groups, classified according to the aetiology of their disease. There were 11 patients with intracranial haemorrhage (either aneurysmal or resulting from an arteriovenous malformation) (median age 51 years). The second group consisted of 52 patients (median age 49 years) with a benign mass lesion: either meningioma, hypophyseal adenoma, or arachnoid cyst. The last group comprised 28 patients (median age 43 years) with malignant neoplastic disease: either malignant glioma, or metastasis. All patients were on steroids perioperatively ( $5 \mathrm{mg}$ dexamethasone three times daily).

The following features were determined by preoperative CT: tumour size (volume in $\mathrm{cm}^{3}$ measured by $4 / 3 \pi r^{3}$ ), perifocal oedema (either present or absent), and midline shift (either present or absent). The midline shift was 
Table 1 CSF and serum concentrations (25th (P25) and 75th (P75) percentiles and median (P50)) of the three patient groups

\begin{tabular}{lllllll}
\hline \multirow{2}{*}{$\begin{array}{llll}\text { Patient group } \\
\text { Variable }\end{array}$} & Unit & $\begin{array}{l}\text { Reference values } \\
(\text { P5-P95) }\end{array}$ & P25 & P50 & P75 \\
\hline Intracranial haemorrhage $(\mathrm{n}=11)$ & MBP & $(\mu \mathrm{g} / \mathrm{l})$ & $0.2-1.2$ & 1.3 & 6.5 & 13.1 \\
& CSF S-100 & $(\mu \mathrm{g} / \mathrm{l})$ & $0.7-2.0$ & 1.4 & 7.5 & 22.90 \\
& Lactate & $(\mu \mathrm{mmol} / \mathrm{l})$ & $1380-1900$ & 2250 & 2338 & 3000 \\
& Qalb & $\times 10^{-3}$ & $1.7-9.0$ & 8.9 & 19.0 & 22.5 \\
& Serum S-100 & $(\mu \mathrm{g} / \mathrm{l})$ & $0-0.05$ & 0.01 & $0.03^{\star \star}$ & 0.07 \\
& MBP & $(\mu \mathrm{g} / \mathrm{l})$ & $0.2-1.2$ & 1.0 & 1.8 & 3.2 \\
Benign mass lesion $(\mathrm{n}=52)$ & CSF S-100 & $(\mu \mathrm{g} / \mathrm{l})$ & $0.7-2.0$ & 2.5 & 10.5 & 30.5 \\
& Lactate & $(\mu \mathrm{mmol} / 1)$ & $1380-1900$ & 1941 & 2644 & 3070 \\
& Qalb & $\times 10^{-3}$ & $1.7-9.0$ & 9.3 & 23.3 & 73.8 \\
& Serum S-100 & $(\mu \mathrm{g} / \mathrm{l})$ & $0-0.05$ & 0.06 & $0.11^{\star}$ & 0.19 \\
Malignant neoplastic disease $(\mathrm{n}=28)$ & MBP & $(\mu \mathrm{g} / \mathrm{l})$ & $0.2-1.2$ & 1.2 & 2.9 & 5.8 \\
& CSF S-100 & $(\mu \mathrm{g} / \mathrm{l})$ & $0.7-2.0$ & 2.8 & 11.2 & 61.6 \\
& Lactate & $(\mu \mathrm{mmol} / 1)$ & $1380-1900$ & 2002 & 2547 & 3549 \\
& Qalb & $\times 10^{-3}$ & $1.7-9.0$ & 8.0 & 18.6 & 45.5 \\
& Serum S-100 & $(\mu \mathrm{g} / \mathrm{l})$ & $0-0.05$ & 0.01 & 0.10 & 0.16 \\
\hline
\end{tabular}

${ }^{\star} \mathrm{p}=0.019$, one way analysis of variance (ANOVA) after logarithmic transformation.

$\mathrm{MBP}=$ Myelin basic protein; $\mathrm{S}-100=\mathrm{S}-100$ protein; $\mathrm{Qalb}=\mathrm{CSF} /$ serum albumin ratio.

defined as a shift of the septum pellucidum of more than $5 \mathrm{~mm}$ from the midline.

The occurrence of breaching of the arachnoid layer was analyzed during surgery only in patients with benign lesions as it is disturbed by malignant, invasive tumours themselves.

MEASUREMENTS IN CSF

All CSF samples were obtained intraoperatively. After opening the dura, $5 \mathrm{ml} \mathrm{CSF}$ was aspirated from the cistern most adjacent to the lesion. Aspiration was performed before lesion or brain manipulation had started.

Immediately after aspiration, the CSF samples were centrifuged ( $1500 \times \mathrm{g}$ for 10 minutes) and an $0.5 \mathrm{ml}$ portion of the cell free supernatant was stored at $-20^{\circ} \mathrm{C}$ for the analysis of the CNS specific proteins. S-100 protein was measured by an immunoradiometric assay according to the instructions of the manufacturer (Sangtec S-100 IRMA, Sangtec Medical, Bromma, Sweden); MBP was determined by a double antibody RIA kit (DSL, Webster, TX, USA). Serum S-100 protein was determined by a commercial immunoluminometric assay (LIA-mat Sangtec 100; Sangtec Medical, Bromma, Sweden). Lactate was determined enzymatically on the COBAS FARA centrifugal analyzer. Albumin was assayed on the COBAS FARA with a nephelometric method.

As no reference values for cisternal CSF were available, reference values for lumbar CSF were used for this study. These lumbar reference values were determined using CSF samples obtained from patients undergoing a diagnostic lumbar puncture for conventional clinical indications such as suspected CNS infection or neurological disorder. The samples thus used to create reference values were selected according to the following criteria: no evidence of an organic neurological disorder, an inherited metabolic disease, or a malignant disease; and a normal concentration of total protein in CSF.

As the reference values of Qalb S-100 and $\mathrm{MBP}$ in CSF are age related ${ }^{7}$ the normal values in this study were taken from the $16-50$ years group (S-100: 0.7-2.0 $\mu \mathrm{g} / 1$; MBP: 0.2-1.2 $\mu \mathrm{g} / 1$; lactate: $1380-1900 \mu \mathrm{mol} / 1$; Qalb: $1.7-9.0 \times 10^{-3}$ ).

Reference values for serum $\mathrm{S}-100$ are $0-0.05 \mu / 1$.
ANALYSES

To describe the serum and CSF-protein concentrations median values were presented together with the 25 th and the 75 th percentiles for each group. These percentiles were computed assuming a lognormal distribution. Differences in protein concentrations between the groups were tested for significance with one way analysis of variance (ANOVA) after logarithmic transformation of the data. Differences in tumour volume between the three subgroups were tested with Students $t$ test after logarithmic transformation. Associations between protein concentrations and the radiological and surgical variables were assessed by Students $t$ test after logarithmic transformation of the protein concentrations. A p value less than 0.05 was considered significant.

\section{Results}

CSF VALUES

Table 1 shows the values of S-100, MBP, lactate, and Qalb. In each group the median values of all four variables were significantly higher than the reference values. There were no significant differences between the values for the three groups except for a significantly higher median concentration of S-100 in serum in the patients with benign intracranial mass lesion compared with patients with intracranial haemorrhage.

As CNS protein concentrations between the three subgroups did not differ significantly, associations between radiological and surgical characteristics and the CNS protein concentrations were assessed for the 91 patients as one group, with the exception of the arachnoid breaching, which was assessed in the benign intracranial mass lesion group only.

\section{Radiological characteristics}

A strong relation between oedema, a midline shift, and a breaching of the arachnoid layer could be documented. All patients in which oedema could be documented $(n=22)$ had a distorted arachnoid layer $(p=0.001)$. In 15 out of 18 patients with a midline shift, a breaching of the arachnoid layer was found at surgery $(p=0.01$, table 2$)$. Furthermore, in 15 out of 20 patients with a midline shift, CT also disclosed 
Table 2 Oedema and midline shift related to breaching of the arachnoid layer

\begin{tabular}{llllll}
\hline & $\begin{array}{l}\text { No of } \\
\text { patients }\end{array}$ & No oedema & Oedema & $\begin{array}{l}\text { No midline } \\
\text { shift }\end{array}$ & $\begin{array}{l}\text { Midline } \\
\text { shift }\end{array}$ \\
\hline $\begin{array}{l}\text { Intact arachnoid } \\
\text { Breaching of arachnoid }\end{array}$ & 23 & 23 & 0 & 20 & 3 \\
Total & 33 & 11 & $22^{\star \star \star}$ & 18 & $15^{\star \star}$ \\
\hline
\end{tabular}

${ }^{\star \star} \mathrm{p}=0.01 ;{ }^{\star \star \star} \mathrm{p}=0.001, \chi^{2}$ test.

Table 3 Associations between CSF/serum concentrations and radiological or surgical characteristics in the total group

\begin{tabular}{|c|c|c|c|c|c|c|c|}
\hline \multirow{2}{*}{$\begin{array}{l}\text { Radiological and surgical } \\
\text { characteristics }\end{array}$} & \multicolumn{2}{|c|}{ Number of patients } & \multirow[b]{2}{*}{$M B P$} & \multirow[b]{2}{*}{$S-100$} & \multirow[b]{2}{*}{ Lactate } & \multirow[b]{2}{*}{ Qalb } & \multirow{2}{*}{$\begin{array}{l}\text { S-100 } \\
\text { (serum) }\end{array}$} \\
\hline & Yes & No & & & & & \\
\hline Oedema & 20 & 40 & $0.02 \dagger$ & - & - & 0.02 & - \\
\hline Midline shift & 18 & 42 & 0.02 & - & - & 0.02 & - \\
\hline Breaching of arachnoid & 20 & 25 & 0.002 & 0.04 & 0.0003 & 0.05 & - \\
\hline Tumour volume & 64 & - & - & - & $0.02^{\star}$ & - & - \\
\hline
\end{tabular}

${ }^{\star} \mathrm{p}=0.02 ; r=0.3 ; r=$ Spearman's correlation coefficient. $\dagger \mathrm{p}$ Value assessed with Students $t$ test; - = not significant. $\mathrm{MBP}=$ myelin basic protein; $\mathrm{S}-100=\mathrm{S}-100$ protein; $\mathrm{Q} a \mathrm{lb}=\mathrm{CSF} / \mathrm{serum}$ albumin ratio.

oedema, whereas in only eight out of 44 patients without a midline shift oedema could be documented $(\mathrm{p}=0.001)$.

\section{Radiological and surgical characteristics and CSF values}

As shown in table 3, the presence of oedema and a midline shift were associated with significantly higher concentrations of MBP and Qalb. Breaching of the arachnoid layer, found at surgery for benign lesions, was associated with significantly higher concentrations of S-100, MBP, lactate, and Qalb. There was a significant positive correlation between tumour size and lactate concentration $(r=0.30, \mathrm{p}=0.02)$.

Serum S-100 versus CSF S-100 values

There was no correlation between serum S-100 and CSF S-100 values. From all investigated patients $(n=65) 46 \%$ had an increased S-100 concentration in serum.

\section{Discussion}

This is the first report on cisternal values of S-100, MBP, lactate, and Qalb during intracranial surgery for intracranial haemorrhage, benign intracranial mass lesion, and malignant neoplastic disease. In each group of patients all four variables were increased above the reference values for lumbar CSF. Reference values of brain specific proteins in cisternal samples are not known. Therefore, we should be very cautious in drawing conclusions from the concentrations of these proteins in individual patients. It has already been discussed by Lamers et $a l^{6}$ that the concentrations of these proteins in CSF depends on several factors, such as the distance between the affected brain area and the CSF compartment, the regional variability of these proteins in the brain, and the possible degradation of these proteins by macrophages and/or proteinases either locally or in the CSF. We think that cisternal samples taken in the vicinity of the lesion provide more accurate information about focal brain damage than lumbar CSF samples do.

Increased concentrations of serum S-100 were found in nearly $50 \%$ of the patients. Two routes of the transfer of S-100 from CNS glia cells into the peripheral blood have been suggested. The first route is by means of reabsorption of CSF into the veins draining the CNS. The second route is directly from the extracellular space via local capillaries into the circulation of the brain. The absence of a correlation between cisternal and serum S-100 values in this study is an important finding and it suggests the second route as the main entry. As transfer of CNS protein over a normal blood-brain barrier is not possible, the increased concentrations of serum S-100 must be caused by a disturbed blood-brain barrier function, probably in combination with an increased cellular release of S-100.

In this study very high concentrations of Qalb were documented in all three patient groups. The association between breaching of the arachnoid and the Qalb increase in the benign intracranial mass lesion group might be explained by the disturbance of the blood-CSF barrier in the cisternal-subarachnoideal space through the breaching of the arachnoid.

Concentrations of MBP, S-100, and lactate, and Qalb were increased in malignant intracranial neoplasms and after intracranial haemorrhage, and also in patients with a benign intracranial mass lesion. In this series, concentrations of S-100, MBP, and lactate, and Qalb in the benign subgroup were not significantly different from the other two subgroups. Therefore, although the clinical relevance of these increased CSF proteins is not yet clear, a conservative therapy or a waiting policy for the patients in whom a benign lesion is suspected, might be reconsidered. Taking into account the relatively short half life of the CNS proteins, this destruction of diverse cerebral cellular compartments seems to be an ongoing continuous process.

This study, although not useful for interpreting the values in individual patients as no reference values for cisternal samples are known, does give relevant information by showing a relation between certain radiological and surgical characteristics and the protein concentrations.

It is suggested that in benign intracranial mass lesion, as in meningiomas, mechanical compression $^{13}$ or perifocal oedema ${ }^{14}{ }^{15}$ causes cerebral dysfunction. This study does not show a tendency for larger lesions to show higher CSF protein concentrations. Compression of a process on the brain, consequently, may not be an essential factor leading to cellular protein release. On the other hand, oedema, which in most cases leads to midline shift, does seem to be an important feature leading to increased MBP concentrations and Qalb ratio. Moreover, arachnoid breaching significantly correlated with higher values of Qalb, lactate, and MBP. As a strong relation was found between breaching of the arachnoid, oedema, and midline shift, these three characteristics may represent a specific pathological cascade resulting in cellular protein release.

Nakagawa $e t ~ a l^{12}$ also reported that increased MBP concentrations seemed to correlate with perilesional oedema in patients with tumours. The concept of cellular protein release caused 
by oedema is an intriguing one. Some patients with oedema spreading diffusely into the white matter do not show any clinical improvement postoperatively, despite "successful" and uncomplicated tumour surgery. ${ }^{15}$ Furthermore, this white matter oedema often results in a persisting perilesional hypodense area on CT at follow up. In these patients the severe oedema might have irreversibly damaged cerebral structures. Thus, in patients with brain oedema and benign intracranial mass lesion there is a surgical dilemma, as probably not the tumour, but merely the oedema is responsible for the increase in CNS specific proteins. The essential point in planning optimal therapy, therefore, is to know if the oedema has led to reversible or irreversible brain damage. Surgery would be indicated in the case of reversible damage, and surgical therapy would be of little help in cases of irreversible cerebral damage. It would be of great help if distinct profiles of protein concentrations could predict neurological recovery chances and outcome. In this first report we did not focus on the postoperative outcome but this will be a major goal in future studies. Correlations have already been found in stroke ${ }^{11}$ and global ischaemia. ${ }^{10}$ Further investigation with larger groups of patients in which cisternal, lumbar, and serum samples are obtained at the same time would be important to clarify the relation between the protein concentrations in these three different fluid compartiments.

\section{Conclusions}

This biochemical report illustrates that intraoperative values of S-100 protein, MBP, lactate, and Qalb are increased in patients with intracranial haemorrhage, benign intracranial mass lesion, and malignant neoplastic disease. The features associated with increase of these proteins seem to be arachnoid breaching, cerebral oedema, and midline shift. Being close to the affected brain area, cisternal CSF might be more representative than lumbar CSF.
Further studies with larger groups of patients are now in preparation to determine possible distinct profiles that can eventually predict neurological recovery.

1 Persson L, Hardemark HG, Gustafsson J, et al. S-100 protein and neuron-specific enolase in cerebrospinal fluid and serum: markers of cell damage in human central nervous system. Stroke 1987;18:911-18

2 Sindic CJ, Chalon MP, Cambiaso CL, et al. Assessment of damage to the central nervous system by determination of S-100 protein in the cerebrospinal fluid. F Neurol Neurosurg S-100 protein in the cerebrosp
Psychiatry 1982;45:1130-5.

3 Sternberger NH, Itoyama Y, Kies MW, et al. Myelin basic protein demonstrated immunocytochemically in oligodendroglia prior to myelin sheath formation. Proc Natl Acad Sci U S A 1978;75:2521-4.

4 Siegal T, Ovadia H, Yatsiv I, et al. CSF myelin basic protein levels in leptomeningeal metastases. Relationship to disease activity. F Neurol Sci 1987;78:165-73.

5 Ross SA, Cunningham RT, Johnston CF, et al. Neuronspecific enolase as an aid to outcome prediction in head injury. Br f Neurosurg 1996;10:471-6.

6 Lamers KJ, van Engelen EB, Gabreels FJ, et al. Cerebrospinal neuron-specific enolase, S-100 and myelin basic protein in neurological disorders. Acta Neurol Scand 1995; 92:247-51.

7 van Engelen B, Lamers KJ, Gabreels FJ, et al. Age-related changes of neuron-specific enolase, S-100 protein, and myelin basic protein concentrations in cerebrospinal fluid. Clin Chem 1992;38:813-16.

8 Ingebrigtsen T, Romner B, Kongstad P, et al. Increased serum concentrations of protein S-100 after minor head injury: a biochemical serum marker with prognostic value? 7 Neurol Neurosurg Psychiatry 1995;59:103-4.

9 Nooijen PT, Schoonderwaldt HC, Wevers RA, et al. Neuron-specific enolase, S-100 protein, myelin basic protein and lactate in CSF in dementia. Dement Geriatr protein and lactate in CSF
Cogn Disord 1997;8:169-73.

10 Martens P, Raabe A, Johnsson P. Serum S-100 and neuronspecific enolase for prediction of regaining consciousness after global cerebral ischemia. Stroke 1998;29:2363-6.

11 Aurell A, Rosengren LE, Karlsson B, et al. Determination of S-100 and glial fibrillary acidic protein concentrations in cerebrospinal fluid after brain infarction. Stroke 1991;22: cerebrospina

12 Nakagawa H, Yamada M, Kanayama T, et al. Myelin basic protein in the cerebrospinal fluid of patients with brain tumors. Neurosurgery 1994;34:825-33.

13 Stevens JM, Ruiz JS, Kendall BE. Observations on peritumoral oedema in meningioma. Part II: Mechanisms of oedema production. Neuroradiology 1983;25:125-31.

14 Whittle IR, Piper IR, Miller JD. The contribution of secondary mediators to the etiology and pathophysiology of brain oedema: studies using a feline infusion model. Acta Neurochir Suppl (Wien) 1990;51:71-3.

15 de Vries J, Wakhloo AK. Cerebral oedema associated with WHO-I, WHO-II, and WHO-III-meningiomas: correlation of clinical, computed tomographic, operative and histological findings. Acta Neurochir 1993;125:34-40. 